
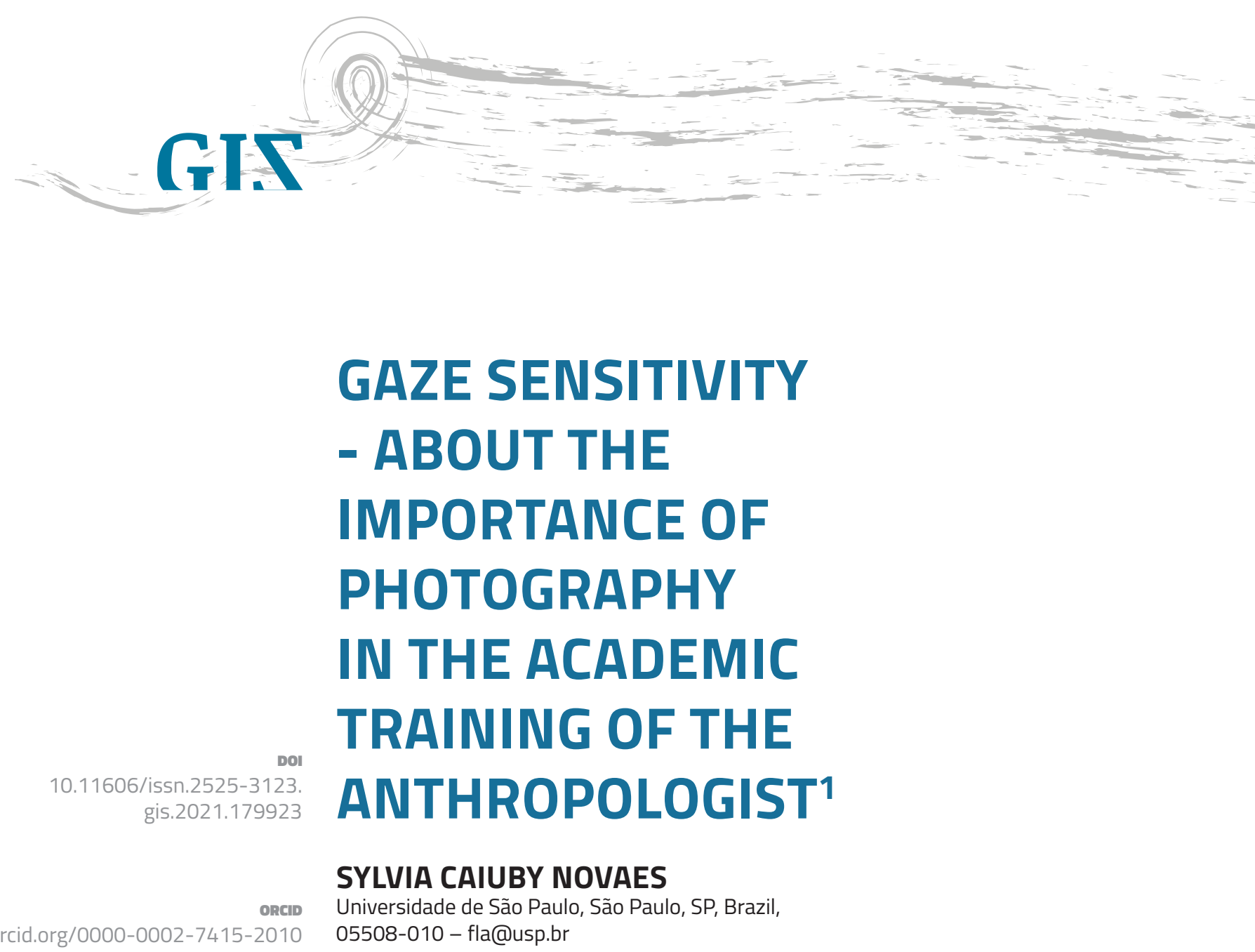

My focus on this essay is not the ethnographic film, but something on which the films, in my opinion, very much depend: the sensitivity of the gaze, an expression that is perhaps more common among photographers. In visual anthropology I dedicated myself much more to photography than to film, an area in which I acted few times.

Anthropology is one of the areas of the so-called Social Sciences in which the verb, the words, the book, the readings, have a predominant role. What I mean is that from the beginning, the training of the social scientist concentrates on learning concepts, theoretical frameworks of the various curricular subjects, the history of these disciplines, the different approaches developed by the various social scientists. In the various courses, the goal is to deepen conceptual, theoretical and methodological instruments relevant to anthropological analysis, which begins in courses with central concepts of Anthropology, such

1 Conference for the Universidade Federal da Paraíba (UFPB), campus Rio Tinto, III Mostra Arandu, cycle of debates on ethnographic films 
as culture, ethnocentrism, relativism and cultural diversity, society, organization, structure, institution, function and social processes. Many courses focus the various theoretical schools of Anthropology, such as evolutionism, diffusionism, studies of culture and personality, functionalism in British social anthropology, structuralism, postmodern anthropology, etc.

More specific courses address themes dear to Anthropology: art, kinship, economics, exchange and reciprocity, religion, myth and Amerindian thought, the social markers of difference such as gender, sexuality, generation, race, class, age, etc. Methodological courses introduce students to the practice of fieldwork, participant observation, the writing of ethnographies, project design and research reports.

I want to emphasize that all of these courses are absolutely fundamental for the training of the social scientist in general and the anthropologist in particular, whatever the area in which he or she will specialize. I value this solid academic background of the social scientist and the anthropologist and my position is that those who dedicate themselves to visual anthropology cannot, in any way, give up this solid formation. After all this is what distinguishes us. We are not filmmakers, photographers, or artists. We are anthropologists.

Of all the social sciences it is Anthropology that most establishes intersections with other areas of knowledge, since the beginning of the history of our discipline: with History, Linguistics, Psychology, Medicine, Law, Economics and also the Arts, in their most diverse forms of expression: dance, theatre, literature, music, photography, cinema, etc.

I think it is extremely important that someone who wants to specialize in visual anthropology, be close to the arts. It was only when I wrote my memorial for the livre-docência at USP, a post-doctorate title, that I realized the importance of arts in my academic training. Since my youth I have always been interested in exhibitions in museums and galleries and I was able to take some art courses.

I had the privilege of attending the Escola de Artes Brasil:, an experimental art school, founded by four artists from são Paulo, who were all, at the time, architecture students: Luiz Paulo Baravelli, Frederico Nasser, Carlos Fajardo and José Rezende; they had all been Wesley Duke Lee students. In the middle of the Medici era (1969-1974), in the context of the most authoritarian years in the history of Brazil, the school was a space of total freedom of expression. Art was thought to be linked to life and did not have a specific training or great talent as a condition. "Art is many things" used to say the teachers. 
Learning was distanced from the "work" and the "market". The important thing was restoring sensitivity through aesthetic education - from repertoires. In this school it was not the expressive means, but the creative processes of teachers and students that should guide learning. The process was always more important than the result, hence the importance of creating repertoire, going to the library, to observe carefully.

There was a lot of experimentation at school and one of the most important was the blind drawing. Design and the creative process were a matter of observation, interest, visual reasoning and experience. The observation design was almost an equivalent of the experience of seeing: the hand that draws go together with the eye that sees. I remember one of the exercises, which was to sit in front of a person, having a narrow table between them, about $50 \mathrm{~cm}$ wide, so that the distance between the two people who sat opposite each other was very small. We had to be silent for about 10 minutes, just watching, which is already a very unusual and even embarrassing experience for many. After 10 minutes of careful observation, we had to start drawing, but the paper was placed on a shelf below the table, so that it was not possible to see what the hand was drawing. I remember drawing Helena Carvalhosa, today a great artist, and that my whole body participated in this gesture that was performed by my hand. It was important not to look at the hands, lest we exercise a critical and self-destructive censorship of what we were drawing. Drawing was the result of the gesture, so it should come with it. Drawings do not necessarily use the entire surface of the paper and it is not necessary to start by thinking about the whole to draw (as opposed to painting). The results were extremely expressive. Escola de Artes Brasil: bet on new ways of making art.

I had two classes a week, 3 hours each. Other artists, such as the photographer Claudia Andujar participated in the workshops. I took a one-year photography course with Claudia Andujar. During classes we stayed for hours around a huge table, just looking and talking about the photos placed on the table. Photos of great photographers like Ansel Adams, Elliot Erwit, Cartier Bresson, Bill Brandt, Eugene Atget, Irving Penn, Pierre Verger, Marcel Gautherot, George Love, all of them photographers with very different styles. The most important was to create a repertoire, as if to absorb the way of looking of these great photographers.

We also went for walks in downtown São Paulo, to photograph the city. Important detail: we photographed without any camera, which according to Claudia could lead us to privilege technique over of the look. With the forefingers and the thumb of both hands we did the best framing of what was being observed. I can say that I continue, to this day, photographing wherever I am, even without a camera. 
The courses at the Escola de Artes Brasil: were fundamental in my academic training. I never became an artist, but these courses provided me with an enormous sensitivity of the gaze. The sensitivity of the gaze depends, as the attitude of any scientist, on strangeness, on a certain relationship even paradoxical, between proximity and distance. It takes a lot of proximity, as in the exercise of observing a person having only $50 \mathrm{~cm}$ between you and them; but distance is also needed, distance here understood as a certain defamiliarization, or a denaturalization of the gaze. We hardly see what is extremely familiar to us, we are so used to it that we are almost blind. Surrealists realized well how to deal with objects that are familiar to us and that they called the photogeny of everyday objects.

Awareness of the gaze is fundamental in the training of anthropologists. We live today in enclosed, confined spaces, which do not allow us to have that sensitive look. And I don't mean confinement imposed on us as a condition of isolation in the current corona virus pandemic. We have long lived in closed walled spaces: the cities are full of walled condominiums, we drive cars, whose windows are darkened, and many of the houses in cities have very high walls, we shop in closed malls, children are now studying in closed schools and stopped playing in the streets. We were already locked up before the pandemic started spreading around the world from December 2019. The pandemic only decreased our circulation space and forced us to a daily life in which the screen, whether on the cell phone, the tablet, the computer, doesn't leave us.

To take a good picture you need to leave these spaces that imprison us and with which we are so familiar. It is necessary to walk, as Tim Ingold appreciates, and observe. As anthropologists we must allow ourselves to get out of books, we have to stop at the whole and in details, discover angles we didn't suspect, observe gestures and features of facial expressions, architectural details, we must pay attention to the minutiae that make part of specific ways of inhabiting and living the world.

Ismail Xavier says, referring to the cinematographic image, that "Every image is the production from a specific point of view: that of the observer subject, not that of the "objectivity" of the image". (Xavier 1990, 379). These observations can effectively be transposed to photography.

The question of the repertoire is fundamental. Just as we read many books, written by many authors, we have to look at photos, from many different photographers, we have to attend photographic exhibitions. Please, realize that a photograph will not be read. We don't read a photo, what we do is to look closely at the image. When looking at it, we recognize or not certain details of its content. Bergson said that the eye only sees what the mind is prepared to know. Franz Boas said, "the eye that sees 
is an organ of tradition". The fact is that no one can see with innocent eyes: without the preconceptions of their time and culture; on the other hand, the broader our repertoire, the more we can see.

In this sense, in addition to the cultural issues that allow us or not to decode a certain image, it is the repertoire of each observer that will lead to the perception of different meanings. The polysemy of the image, its multiple meanings are not in the image itself, but in the reception.

Images have this enormous power of evocation, which depends on the experience of those who observe it, their life history, and their memories.

José de Souza Martins sees the photographic act as an imagined construction, the expression and moment of the act of knowing society with resources and unique and peculiar horizons. The image often demonstrates the insufficiency of the word as a document of social awareness and as raw material of knowledge. Paradoxically, images allow us to better understand how to read "between the lines", the implied meanings.

We can read articles on hunger in Africa, analyses, information, and statistical data. Images can be more eloquent. Kevin Carter, a South African photographer won in 1994 the Pulitzer Prize for photography by portraying a scrawny and dying Sudanese girl, with a vulture beside her that just waited for its final moment. It is known that the photographer committed suicide months after the award.

Photographs are not the only images that move us by the sense of reality they provide. As social scientists, we've read countless critical texts about institutions such as the State, the Church, the Army and the family. Goya's prints, - I think especially of the Los Caprichos series and The Disasters of War, which moved the 18th century-, continue to make a big impact on us by the strength of what they visually present. Apocalypse Now, a 1979 film by Francis Ford Coppola, certainly brings the viewer closer to the horrors of the Vietnam War unmatched and in my opinion surpasses Conrad's novel that inspired the film. I myself tried to address socio-economic inequality in Brazil in a video clip in which the coldness of statistical data could be replaced by the irony of photos from magazines like Caras and Chic and Famous, with the background music Weekend in the Park, by Racionais.

But why emphasize the importance of photography in the academic training of anthropologists?

Today I have no doubt that photography is an excellent resource for someone to start fieldwork in order to produce ethnographies. Firstly, because photography allows you to change the focus - from the verb to behaviour, 
body, gestures, details about which it is not always possible to talk. With photography we can leave the famous interviews, which often very much impoverish the ethnography. The photos show immediately whether the researcher was able or not to have a greater intimacy with the chosen subject and the people. Without getting close a good photo is impossible. In this sense, photography, which is essentially silent, is more important than the act of filming; as social scientists we are always running the risk of filling everything that was not observed and recorded in the film with those boring interviews, of natives and experts.

In field research, photography can be a stimulus for the researcher to get closer to the universe he wants to know. The act of photographing implies empathy and certainly intersubjectivity. It is very difficult to photograph in environments we do not belong to without establishing a relationship of trust, intimacy and empathy. The camera, on the other hand, is an instrument that requires careful observation, a sensitive look and a certain denaturalized way. As with all good research, to photograph it is necessary to wonder - or to denaturalize the look - and at the same time to get close. Distance and proximity are, as we said, fundamental ingredients of both the good ethnography and photography. To photograph also implies a type of knowledge that does not go by the word, but much more with the sensitivity of the look, the intuition, the capacity to be in the right place at the right time, due to the sensitivity of placing the body (and the camera attached to it) at the correct distance. Photographing implies good relationship to be established with the people we photograph. It's equally important in the act of photographing deciding what will be in focus and what will be out of focus, or if everything the photo shows will be in focus. I have no doubt that these skills are fundamental for the good fieldwork.

I participated in 2018 in a photographic exhibition of works made by anthropologists, curated by Fabiana Bruno and entitled Confidences of images in Anthropology, ways of seeing, thinking and interrogating. There are two meanings connected to the word confidence in the title of this exhibition that I would like to emphasize: secrecy and intimacy. Secret and intimacy because the photographs, drawings and objects gathered in this exhibition of anthropologists reveal much of their authors, as if these were their secrets; on the other hand, they are images and objects that reveal feelings of affections between anthropologists and their research partners, a relationship of intimacy and complicity with the theme and their interlocutors. Secrecy and intimacy that we would hardly achieve with the academic text, which we share with the other Social Sciences, as Sociology and Political Science. On the other hand, I want to emphasize that the researcher must be fully aware of the images he wants to see published about his research partners, his interlocutors. This is an 
ethical issue. Images contribute, as the name says, to the construction of the image about that people.

My conviction is that, of all the disciplines that make up the Social Sciences, it is Anthropology that comes closest to the sensitive side of social reality in which all are concerned, and, on the other hand, Anthropology is the one that most approaches the arts and incorporates, in its own way, the languages that arrive from these fields, such as photography, drawing, cinema, etc. For a very simple reason: more than sociologists and political scientists, are we anthropologists who, in our research, look for a true immersion in these other worlds that we are willing to understand. Field research involves face-to-face relationships for the extended time where we live in these other empirical universes. We do not work with questionnaires and we know that interviews, even unstructured ones yield little and mean, in general, opaque communication with our interlocutors. Mutual trust relationships are our main research instruments, and we know how long it takes to be established.

Photography has, in my view, a certain association with the narrative about which Walter Benjamin speaks so well. He already said, "the experience that passes from person to person is the source that all narrators use. And among the narratives, the best ones are those that are least distinguished from oral stories, told by countless anonymous narrators" (1996:198). The narrator, according to Benjamin, takes from the experience what he tells - his own experience or what others report. When narrating he incorporates the narrated things into the experience of its listeners.

I would say that both photography and narrative have this ability (which is not given to the academic text or journalistic information) to welcome the experience of those who contemplate or listen. A welcoming that awakens in those who hear or contemplate new reflections, about their own experiences. By hosting the photograph, I mean that it is sufficiently "open" so that the observer can dive in it and, paradoxically, perceiving in him/herself what the photo awakens. When we see something, we see not only the appearance of the thing that the image shows us, but also the relationship we have with this appearance. Images stimulate the imagination and can lead us to establish relationships before unsuspected.

The narrative does not explain; like photography, it evokes. The art of narrating imprints the mark of the narrator in the narrative, just as the good photo brings the sensitive eye of the attentive photographer when capturing it.

The interview is very different, be it that of the native or that of the specialist in the subject that we are dealing with and that populates most 
of the contemporary ethnographic films. The interviewee only responds to questions previously asked by the researcher and speaks in front of the camera with minimal involvement. There are almost no gestures; the speech that comes to the camera is practically a ready speech. We do not see in the interviewee a dip in the subject that requires him to work on memory. This is certainly not a rule that applies to any and all interviews. Claude Lanzmann, director of Shoah and Eduardo Coutinho are great masters of the interview.

On the other hand, I would say that photography is an excellent ally for the researcher in the field. Taking to the field the photographs that we took of the people is essential in a long-term relationship. Furthermore, as the photos stimulate conversations, it is always possible, in the field, to insert photos on the themes that we want to discuss with our interlocutors, without the topic falling from the sky. Photographs yield conversations that would certainly be impossible without them. How to talk about funerals if none is taking place when we are in the field?

In terms of presenting research results, photography can bring to Anthropology a new, more sensitive horizon, from which it will even be possible to elaborate a speech closer to our research partners. Here I launch another interesting challenge for contemporary anthropology and, more specifically, for experimental ethnography. See that I am not referring here to the image as an access route to the imaginary, but to the image as language. This is another challenge, to be taken seriously and with the desired competence. Images much more evoke than explain. After the crisis of representation that affects human sciences from the mid-1980s, languages like photography and cinema can be inspiring. A writing that incorporates assembly, simultaneity, polyphony and non-continuous narrative, which cinema has been using for almost a century, should encourage us as anthropologists to problematize our notion of culture, to review the increasingly present deterritorialization in the groups we study, and fundamentally they could stimulate us experimenting with new narrative structures.

When photographing the researcher isolates some fragments of the universe that he investigates. This spatial cut out highlights some aspects of the photograph. As anthropologists we know that the results of our research are greater when we look at universes of a more reduced scale. Our micro approaches are usually more interesting than our macro approaches. This is also how photography works. Nobody photographs reality or society. Like ethnography, photography gives us the feeling of incompleteness, neither one nor the other can cover everything, they are always fragmentary, they cut out a field on which they deepen, in a dive that is, at the same time, sensitive and intelligible. This can only 
mean a gain for us. It is the eloquent silence of images that we can take to our discipline, with everything that, in their own way, photographs have to say.

\section{BIBLIOGRAPHIC REFERENCES}

Benjamin, Walter. 1996. "O Narrador - Considerações sobre a Obra de Nikolai Leskov". In Magia e Técnica, Arte e Política - Ensaios sobre Literatura e História da Cultura de Walter Benjamin. Obras Escolhidas, Volume 1. São Paulo: Editora Brasiliense. 197-221.

Conrad, Joseph. 2019 [1902]. Coração das Trevas. São Paulo: Ubu.

Martins, José de Souza. 2008. Sociologia da fotografia e da imagem. São Paulo: Contexto.

Xavier, Ismail. 1990. Cinema, Revelação e Engano. In O Olhar Org. Adauto Novaes. São Paulo: Companhia das Letras. 367-383.

\section{FILMS}

Coppola, Francis Ford. 1979. Apocalypse Now. United States.

Lanzmann, Claude. 1985. Shoah. Paris, France.

\section{ABSTRACT}

In this text, I try to associate anthropological field research to the photographic act itself, showing what is common in these two activities: the need for clipping, proximity, intimacy and empathy, the decision about what will or will not be in focus. From my experiences at the Escola de Arte Brasil: I talk about the awareness of the gaze, the need to create repertoires and the opportunity that photography offers to change the focus - from

KEYWORDS

Photography, Field research in Anthropology, Eye awareness. the verb to behavior, the body, the gestures, the details about which it is not always possible to speak. I also try to emphasize the association of photography with the narrative that Walter Benjamin talks about, the ability of both the narrative and the photography to welcome the experience of those who hear or contemplate it.

Sylvia Caiuby Novaes is Anthropologist, Full Professor at the Department of Anthropology at Universidade de São Paulo, Coordinator of LISA - Laboratory of Image and Sound on Anthropology and GRAVI - Visual Anthropology Group. She is 1B Researcher from CNPq (301161/2018-6) and from FAPESP (2018/21140-9). E-mail: scaiuby@usp.br 